\title{
Anthrovision
}

Vaneasa Online Journal

$3.1 \mid 2015$

Varia 3.1

\section{Approaching Fluid Silence in the Context of Cancer in Japan}

Visual Microanalysis on the Ethnographic Film, Ippo Ippo (2010)

\section{Shotaro Wake}

\section{(2) OpenEdition}

\section{Journals}

Electronic version

URL: http://journals.openedition.org/anthrovision/1453

DOI: 10.4000/anthrovision. 1453

ISSN: 2198-6754

\section{Publisher}

VANEASA - Visual Anthropology Network of European Association of Social Anthropologists

\section{Electronic reference}

Shotaro Wake, «Approaching Fluid Silence in the Context of Cancer in Japan », Anthrovision [Online],

3.1 | 2015, Online since 29 November 2015, connection on 19 April 2019. URL : http://

journals.openedition.org/anthrovision/1453; DOI : 10.4000/anthrovision.1453

This text was automatically generated on 19 April 2019.

(c) Anthrovision 


\title{
Approaching Fluid Silence in the Context of Cancer in Japan
}

Visual Microanalysis on the Ethnographic Film, Ippo Ippo (2010)

\author{
Shotaro Wake
}

\section{Introduction}

1 In this article I will present and develop the concept of fluid silence captured through micro observations and analyses of a scene in my documentary film, Ippo Ippo (2010). The film casts light on the relationship between a Japanese married couple where the wife experiences breast cancer and has partial blindness. As many studies have concluded, illness is accompanied by different forms of suffering, including emotional and physical pain, that are not easy to speak about or listen to. Many Japanese people prefer to anticipate, articulate and respond to suffering through the use of indirect communication, including silence (Ohnuki-Tierny 1984; Kakai 2002). The couple in the film show a preference for communicating in this style.

2 Anthropologists have studied different forms of silence. For instance, there are experiences that are not socially acceptable to speak about and there are also those that exist beyond the limit of language (Basso 1970; Collins and Bell 1998; Huby 1997; Jackson 2004). Silence in Japan is active communication (Lebra 1987; 2004) and is not merely the absence of speech, such as a gap, pause, or empty space that needs to be 'filled in' (Crapanzano 2004). According to Hendry, "The spaces in conversation are also said to be vital to obtain a deep understanding of what is being communicated. Often what is not said is just as important as what is said." $(1993,165)$. As will be evident in the scenes I will present here anthropologists are faced with a challenge when experience is not verbalised or only partially verbalised. 


\section{The Anthropological Obsession With Talking}

3

Before entering the theoretical discussion about indirect communication styles, including silence in the context of Japan, I will briefly look at the social and existential limitations and possibilities that exist in communication. For instance, people do not always know what to say and some things cannot be easily expressed in words in certain situations. In particular, serious pain, deep sorrow, and traumatic memories create communicative difficulties between the sufferer and the other. According to Scarry (1985), pain is an absolute certainty for the sufferer while the listener may question or doubt this suffering because people do not have objective, independent access to the inner experience of someone else. Yet, Polanyi (1969) argues that we may still be able to know something about the experience of others through their externalisation of verbal and non-verbal expressions. Also, their outward suffering is not merely something to acknowledge or perceive because it affects and elicits responses in others through affective and imaginative capacities such as empathy (Hollan 2008; Throop 2008).

To approach the experience of others, Katherine Ewing (1990) offers a useful framework. She critiques the anthropological framework of self as a static and fixed entity. In her framework, selves are fluid through use of language; they constantly shift and contradict from moment to moment within the self and between selves through use of language. The idea is tempting and inspiring; however, her ethnographic description captures shifts on only a verbal level related to what is "say-able", and does not incorporate the shifting motions in the realm of silence. In fact, Merleau-Ponty (1968) encourages us to investigate the mutual relatedness between speech and silence. "Language realizes, by breaking the silence, what the silence wished and did not obtain. Silence continues to envelop language; the silence of the absolute language, of the thinking language" (176).

\section{Silence and Indirect Communication Style in the Context of Cancer in Japan}

5 Silence is a form of active communication in Japan (Lebra 1987; 2004). People, especially the older generation, "prefer an implicit, nonverbal, and intuitive communication style over an explicit, verbal, rational exchange of information" (Kakai 2002, 364) in order to maintain social relationships. To prevent hurting each other's feelings, which Lebra calls "as fragile as eggshells" (1976, 43), Japanese people generally follow norms of politeness and formality related to how to express themselves in speech and attitude. KagawaSinger (1993) shows an excellent example of indirect communication styles in the context of cancer. She interviewed an elderly Japanese-American husband who behaved 'as if not knowing' about his cancer diagnosis, although "by speaking about it in the manner he did, he clearly showed me that he did know" (300). Interestingly, Kagawa-Singer thinks that both the husband and the wife were trying to tell her that he knows it without verbalising it directly. She explains the husband's motivation in the following way:

It seems he had concluded that "knowing" would not really change his life, so if his family and doctor did not want him to know, he would comply. In this way, he could maintain his daily routine and make plans for trips as he would have before the surgery. He was able to maintain the illusion of not knowing he had cancer and thus not be an emotional burden on his family because they would not feel 
obligated to directly offer him emotional support for a potentially fatal diagnosis. He was able to achieve a "smooth" recovery and avoid a culturally awkward family situation, and thereby maintain the cultural objective of harmony in their relationships. (Kagawa-Singer 1993, 300)

On the surface, the husband's pretence of 'not knowing' can be seen as avoidance but it can also been seen in the context of an expression of empathy, omoiyari, towards his doctor and his wife who do not tell him. In addition, his wife is also being empathetic towards her husband because she acts as if she is unaware that he is pretending not to know. Kagawa-Singer argues that this is not about a denial of the reality, but a demonstration of their way of dealing with the hard reality. According to Ohi $(2011,43)$, by 'pretending to not know', shiranai-furi, about one's characteristics of illness, a person with cancer can go on performing his or her role as 'a patient' who would recover from the illness that he does not know about, and so that he or she can maintain the harmony in his relationships. However, this is a burdensome virtue for the person since he or she also needs to keep difficult emotions that cancer evokes intensely, such as fear, anger, sadness and worry, to himself. It implies that by remaining silent, the person's belief (for instance, 'cancer equals death') can very well remain still and fixed. The person would have fewer occasions to be involved in dialogues with others, dialogues which can potentially shape negative beliefs in a positive direction even if talking itself provokes uncomfortable feelings (for instance, 'living with cancer'). Thus, the negative consequences of this creative space created by a tacit agreement between patient and family needs to be considered. For instance, Susan Long writes of a family member who provides comfort for a patient that "[i]n spite of his own feelings, he should go on acting 'normally, as if nothing had changed, and do his crying in private" (1982, 2104). This implies that a patient's suffering is visible as he receives emotional support from his family, but the family member's sorrow remains unseen to the patient and also to the health professionals. In summary then, it shows how the ambivalent creative space nourishes a collaborative act of maximising ambiguity presented through silence or not talking, which in turn can nourish hope and a sense of continuation of life. However, it can also be a source of misery and disappointment if one person's suffering is hidden behind the need to support others.

7 Hendry (1993) would explain the practice of maximizing ambiguity between the wife and husband as a cultural practice of "wrapping" which has its own ethic and aesthetic. When researchers approach such practices, they need to be extra careful about our eagerness of seeking 'accuracy' in knowing by unwrapping the consciously underlying emotions in people. Hendry argues that "the problem may lie in our Western propensity to want always to be unwrapping, deconstructing, seeing the objects at the centre of things." Hendry reminds us, "what we need to do, is to learn to value the wrapping, as well as the wrapped, and seek the meaning they together convey" (ibid, 109). In this sense, KagawaSinger seems to understand such value as she shows sensitivity towards the couple by not verbally confronting them with questions which can elicit emotional reactions because this could not only ruin their wrapping, their difficult efforts not to talk, but also what they have wrapped - maximised ambiguity concerning the scary possibilities of the future as a means of caring for each other. Kagawa-Singer shows that the couple are not merely passively avoiding it but creatively producing a sense of well-being and self-integrity in the current frantic life situation (ibid, 295). However, Kagawa-Singer's ethnography lacks a description of the role of the body in their communication, on how she comes to understand these 'cues' from the couple. This article aims to enrich the ethnographic 
understanding of indirect communication styles to help us approach what people are communicating. Caution is needed not to overlook the role of silence in communication because the researchers who pay great attention to non-verbal communication have a tendency to treat silence as a 'pause,' or 'gap', or as a means for someone to take their 'turn' in a conversation (Sacks 1974). Again, this approach overlooks people's intentions, considerations, and efforts that lie behind silence in relation to those with whom they communicate.

Therefore, silence needs to be treated as a mode of being. How does the choice between verbal utterance and not talking correlates with facial and bodily expressions to create a meaningful whole? How does this dynamic function through ongoing interactions which also include the researcher?

\section{Visual Microanalysis as a Vehicle for Approaching Fluid Silence}

9 To approach the realm of silence captured on film, my main methodology is to conduct 'a new fieldwork' at a micro level of the videotaped scene. Reviewing a particular scene many times and in detail, allows the researcher to see a new horizon of meanings which would otherwise go unseen because they happen too quickly to be observed during a single viewing of the film from beginning to end. Watching many times becomes a process of "defamiliarization, alienation, or self-distancing" (Crapanzano 2003, 4). It especially allows the researcher to access visual details such as the role of the body in indirect communication styles, crucial access points for interpretations, and how language and body together convey meanings of how, for instance, a couple interpret and react to each other's silence. To understand better how the couple I chose to follow were communicating I found it useful to include the role of the researcher in the film. Although the body of the researcher who is filming is not visually present as an image, I argue that by focusing on his camera framework, movement, and the timing of when filming starts and stops, together with his utterances and interaction with people in the film, we can achieve a good sense of how the researcher in the film interpreted and reacted to the silence of the protagonists at the time in the field.

To enrich the understanding of the context of the scene, I will also bring in follow-up interviews from the most recent research I did on how people in the film, and those in similar situations, understand the scene. Moreover, I will also compare and contrast the behaviours of the couple in the film with other situations where they were filmed as the aim of the article is to understand silence as a mode of being that constantly shifts, from moment to moment, within the self, and between the selves in ongoing interactions. Lastly, by the end of the article, the reader will know that a reinterpretation of the scene can provide an alternative, yet empirically grounded, way of explaining the attitude of the husband towards his wife - from being seen as cold to more empathetic.

The reader will encounter numbers of hyperlinks next to the text throughout the article that have access directly video clips from the film and other materials uploaded on a popular video-sharing site (Vimeo). This is to provide readers with easy access so they can read and watch to make sense of what is going on. I think this is preferable to articles where readers are asked to prepare and watch the films in a format like a video or DVD and are then instructed to fast-forward or rewind the film according to the text. This can 
be rather draining and discouraging for the reader and it would be especially so in this article: the reader is invited to watch video clips a numbers of times to observe tiny details of an ever changing dynamic of bodily communication in the interactions. I believe by increasing technological comfort for the readers they may feel more free and willing to read the paper and view the visuals. It also helps the author to seek sophisticated critique from the reader about the validity and credibility of his or her arguments based on the use of visual media. The format presented in the online journal would have been a 'dream' to Margaret Mead (1995) who together with Gregory Bateson tried out sequential photographic analysis on behaviours of Balinese (1945).

\section{PART I - The Tension Between Wife and Husband - What is it About?}

The film is based on five months of fieldwork I conducted at a local cancer support group, 'Ippo Ippo No Kai' (The Group Step By Step), in Shizuoka, Japan in 2009. I joined the group not only as a researcher but also a former cancer patient and became their latest cancer member. The narrative follows Marsha in her steps toward deciding whether she will participate for the first time in the annual support group event of climbing Mt. Fuji, Japan's highest mountain (3776 meters). My research interest emerges from my own cancer experience when I was treated alone in the United States while I was an international student from Japan. I became curious about how participants of a Japanese cancer support group try to maintain positive personal and social relationships in their everyday lives after being diagnosed with cancer.

13 I now encourage the readers to watch the opening scene of the film. The scene starts when Marsha-san visits her husband, Shimo-san, for the first time at the tennis court where he enjoys playing tennis with his friends almost every weekend.

This media file cannot be displayed. Please refer to the online document http:// anthrovision.revues.org/1453

In the opening scene the audience feel and sense that both Marsha-san and her husband seem to find each other strange and distant. This starts before they meet when Marsha's expectations are let down when she finds that her husband is not there to greet her at the gate. Her visit was a special occasion. For the first time in ten years Marsha-san dared to come and see his passion for playing tennis in action. But it did not turn out to be a fun experience, and they ended up hurrying back home.

On the surface, the subtle tension seems typical of a middle aged married couple maintaining the balance in their relationship after they have finished raising children. A wife intrudes on her husband's personal space in public and her husband reacts to this by offering an unfriendly attitude. In fact, Marsha-san herself was passionately engaged in a conversation with women at the benches about the ideal of keeping hobbies and interests separate between husband and wife. Particularly important given that their children have now grown up, this allows both of them to nourish a web of social relationships different from each other so that they can feel free to engage and enjoy moments with their own circle of friends (Ippo Ippo 2010, 00:06:02 - 00:06:43). However, it will become evident that keeping their interests separate has an extra importance in terms of their life together dealing with chronic disability and illness. 
17 On the way to the tennis court Marsha-san told me that it was difficult for her to understand why her husband kept playing tennis, especially during the period when she had to go through chemotherapy treatment for her breast cancer. "He played tennis before I became ill. But, even when I became sick, he did not stop. I thought why does he go at such a time, I thought he could pat my back [to comfort me], but now I think this would not have helped me that much. Why did I think in that way? I must have been frustrated." She then kept quiet for a long time. I felt her latent anger and sadness from the way she told me. That Shimo-san left to play tennis in the midst of her cancer treatment seemed to create a sense of distrust in Marsha, and it has become a painful memory.

However, what Marsha-san did not seem to grasp at the time of our visit was what it meant for Shimo-san to keep playing tennis, particularly at the time when his wife was going through the cancer treatment. Shimo-san once told me that it was exactly because of this difficult time that he needed to continue playing tennis. For two decades he had been supportive of his wife - first with her partial blindness and later on also with her cancer treatment. Moreover, during her cancer treatment, he also had to deal with other stressful family issues such as the health problems of his grandmother, the high school entrance exam of his son, and two hours of commuting to work every day. It was a heavy burden to survive under all the pressures and responsibilities as a householder, a father, a son, a husband, and a caregiver. Moreover, his wife's serious illness evoked his own existential issues such as realising that his own health might also be temporary. He can no longer take his own health for granted. I understand why Shimo-san told me this in a shameful, somewhat defensive way. He knows that his personal need for his hobby contradicts the expected image of a "good caregiver" in the world of illness. Good caregivers in a Japanese sense, according to medical anthropologist and Japan expert Susan Long, are those who protect, endure, and self-sacrifice themselves for the wellbeing of the ill family member (2004).

In a contradictory way, Shimo-san's seemingly 'inappropriate and 'bad' care giving behaviours, such as pursuing his own interest in midst of his wife having a hard time, refreshes him and provides a sense of wellbeing so that he can continue to be a good caregiver. In Gay Becker's term, playing tennis is his way of "restoring the sense of normality and continuity in middle of the chaotic life situation" (1997). What the couple did not seem to talk about openly was the burden felt by Shimo-san as a caregiver. I imagine that this is not a unique situation for those in a similar situation in Japan. In the case of Marsha-san and her husband, the non-verbalised issue manifested in silence becomes vividly elicited through the awkward encounter when she sees him in a different situation, among people she does not know, in a world she has little access to and understanding of. Radley discusses how a person with a chronic condition, as is the case with many types of cancer and handicaps, still has to live in the world of the healthy where they feel like they do not belong (1993; 2009). If I think of the world of the healthy, a tennis court represents one of the most vividly healthy places. For Marsha-san, who cannot even see the movement of the ball, this healthy place could even be a dangerous place.

In the following I will closely examine how they negotiate their boundary of privacy and autonomy, not simply as a wife and husband, but also as a long term care-receiver and caregiver in a place where they find each other strange and distant. By closely examining how the process of their subtle conflict emerges, and how they make effort to recover 
from it, I am forced to pay attention to their bodily communication, particularly during periods of silence.

\section{Part II - Silence and the Verbal Expression of "Hot"}

21 In the opening scene the viewers hear the word, "Atsui", ("Hot" in English) eight times. Marsha-san mutters it to herself three times and the other uses are between her and her husband in their conversations. The semantic meaning tells us that she is expressing something about her physical state; she feels very warm underneath the strong sunlight on a warm summer day. However, I argue that by following only the semantic meaning of her expression we will have little clue about her full experience. After exploring the pragmatic meaning in her expression of "Hot" in relation to what takes place in and around her silence, the readers understand how its meaning shifts each time according to her state and interactions with others. To clarify the deepness of the pragmatic meanings I start from the moment when she says "Hot" for the second time while standing in the middle of the field.

\section{How to approach her husband at the tennis court?}

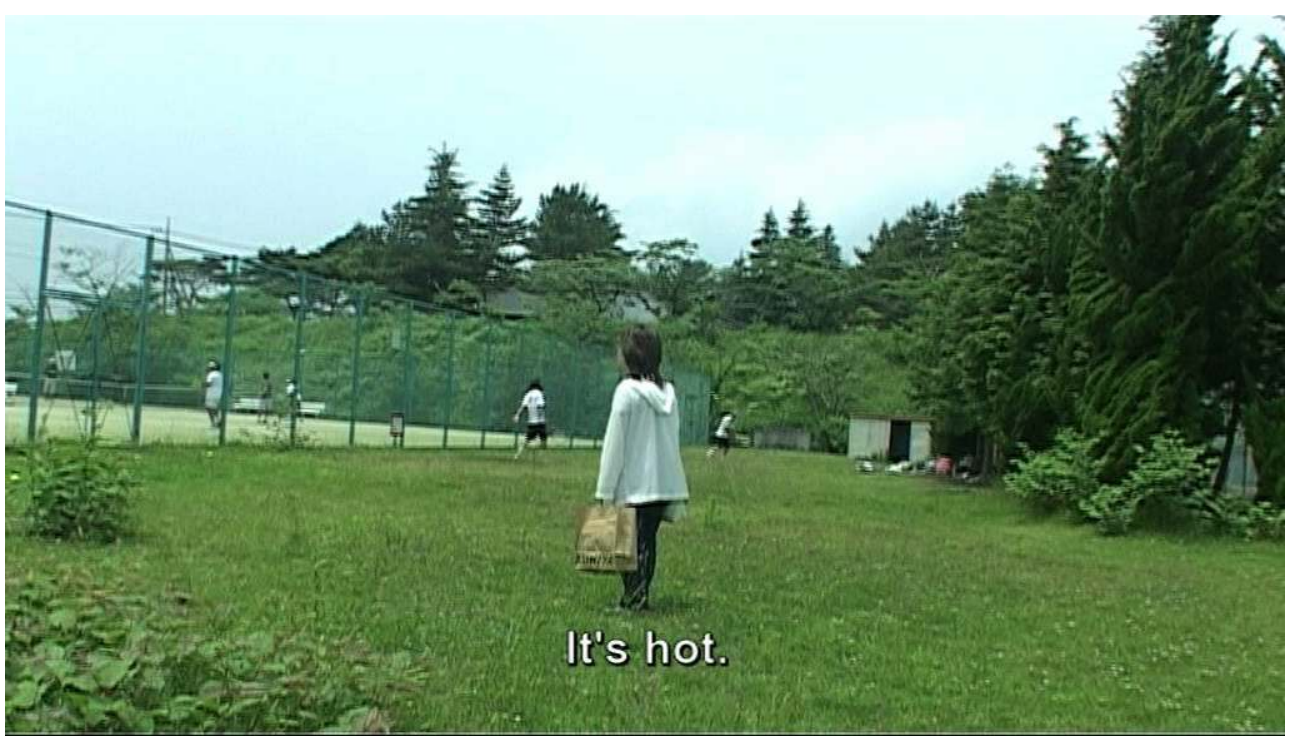

Screenshot of the film "Ippo Ippo" by Shotaro Wake 2010

At that moment I was filming her at some distance from behind, and I could hear her muttering the word from the microphone attached to her. Because she was looking away, and we had the physical distance between us, I thought she was talking to herself when she said, "Hot". However, from micro observations, I came to realise the complexity around the expression which I overheard during editing. For instance, she mutters with a tiny voice "Mai..." and "Doko..." right before she says "Hot" (Ippo Ippo 2010, 00:02:04 00:02:13). These mutterings have not been subtitled because, again, I overheard them during the editing process. In the following link "Mai" and "Doko" are embedded in the subtitles.

23 [Video: Mai and Doko]

Click here to watch video: https://vimeo.com/104283349

Excerpt of the film "Ippo Ippo" by Shotaro Wake 2010 

half words or half sentences, and their meanings are unclear and some imagination is required to grasp their full meanings. If I were to guess, "Mai..." stands for "Maitsutana "(what should I do?) and "Doko..." stands for "Dokokana"(where...?). They seem to indicate that she does not know where or how to find her husband. This interpretation is in line with what she has already said; "If he doesn't see me. I can't approach them." Her body also seems to correlate with the meanings of the fragments of words; for instance, she says "Mai" and uncomfortably looks around to the left and right, and says "Doko..." while she lifts up her left leg as if trying to make a move, but she does not. Instead, she stands still and says "Hot" as if she is nailed to the ground. It leads me to a deeper understanding about her inner state. She seemed to say "Hot" because she hesitates to show me that her husband is not coming to pick her up, yet she does not know how to approach him without my help. Interestingly, feeling hot under the burning sun may be the only certain thing she experiences in this uncertain situation and in this unfamiliar place.

ber seeing her standing alone in front of my camera, amplifying intensely my feelings of awkwardness and guilt, which made me more aware about my carelessness in prioritising my interest of filming over accompanying her as a guide because of for her poor eyesight. As is evident in Huby's work of silence (1997), silence calls for interpretation and actions, and her silence communicated to me in a way that elicited guilt for not acting appropriately in this setting. It was as if I was waiting for her to make the next move and I felt increasingly affected by her silence. Indeed, it was me who could not take her silence any longer and made the next move. I stopped filming, approached her, and accompanied her to the people at the bench to, in Montagu and Matson's term, "make an entrance" $(1979,2)$ for the encounter. Marsha-san accepts my initiative without words and starts to walk towards the people at the bench.

The author's filming position and angle

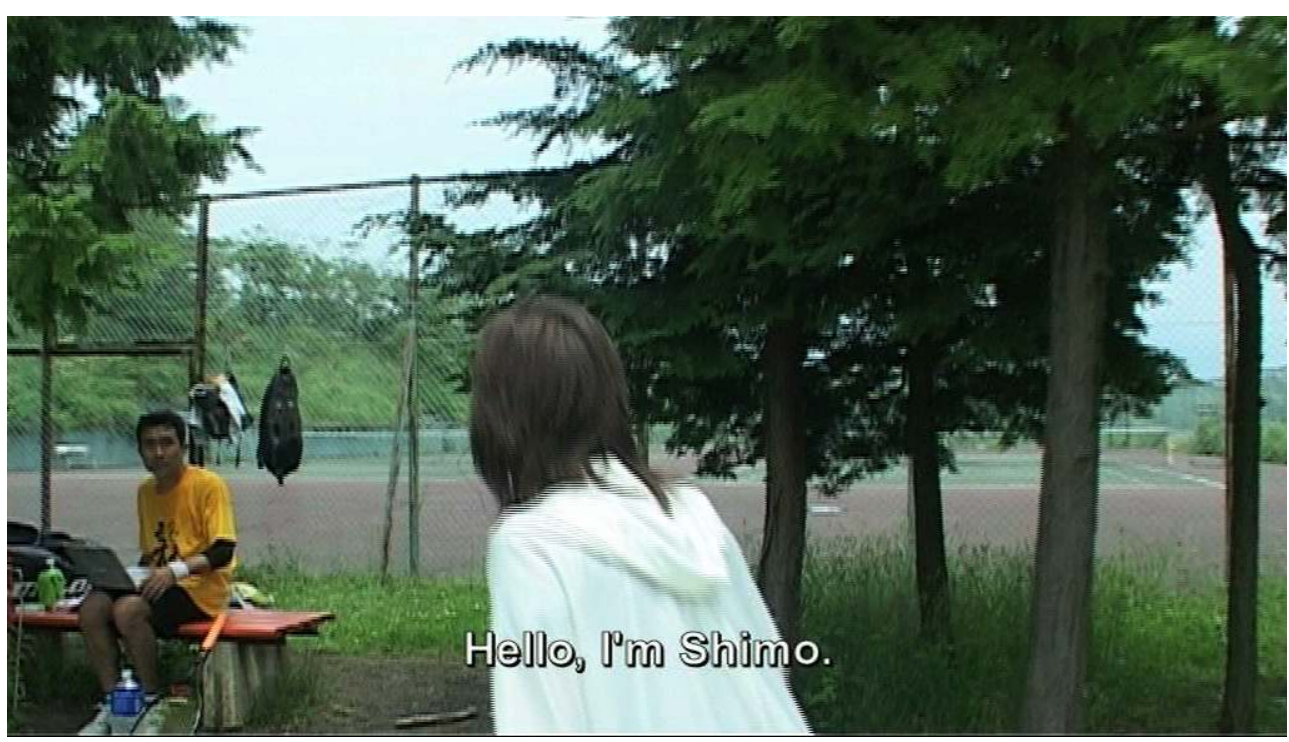

Screenshot of the film "Ippo Ippo" by Shotaro Wake 2010

As shown in the photo above, I stand slightly behind at the left side of Marsha-san and start my camera again just before she greets them vocally. This suggests that what is visually missing between the shots is the moment when I shift my role to a seeing 
assistant rather than a camera man. In the moment when the camera is off and visual material is missing I seem to work to set the stage for an encounter between Marsha-san and the people at the bench.

This microanalysis shows that her utterance of "Hot" becomes an index of (and illuminates the boundary between) knowing and not knowing, of being able and unable, and of hopeful and hopeless. Importantly, my reaction underlines that her experience is not an isolated disconnected 'personal' entity, but a shared one. The silence was running fluidly between us, communicating. Using this logic, silence too is a dynamic phenomenon where ongoing interactions constantly shape meanings. In the next section, I will look more closely at how fluid silence is shaped between Marsha-san and her husband at the tennis court.

\section{"Hot" as an Expression of Reclaiming Each Other in an Unfamiliar Situation}

\section{Expressions of "Hot" between Marsha and her husband}

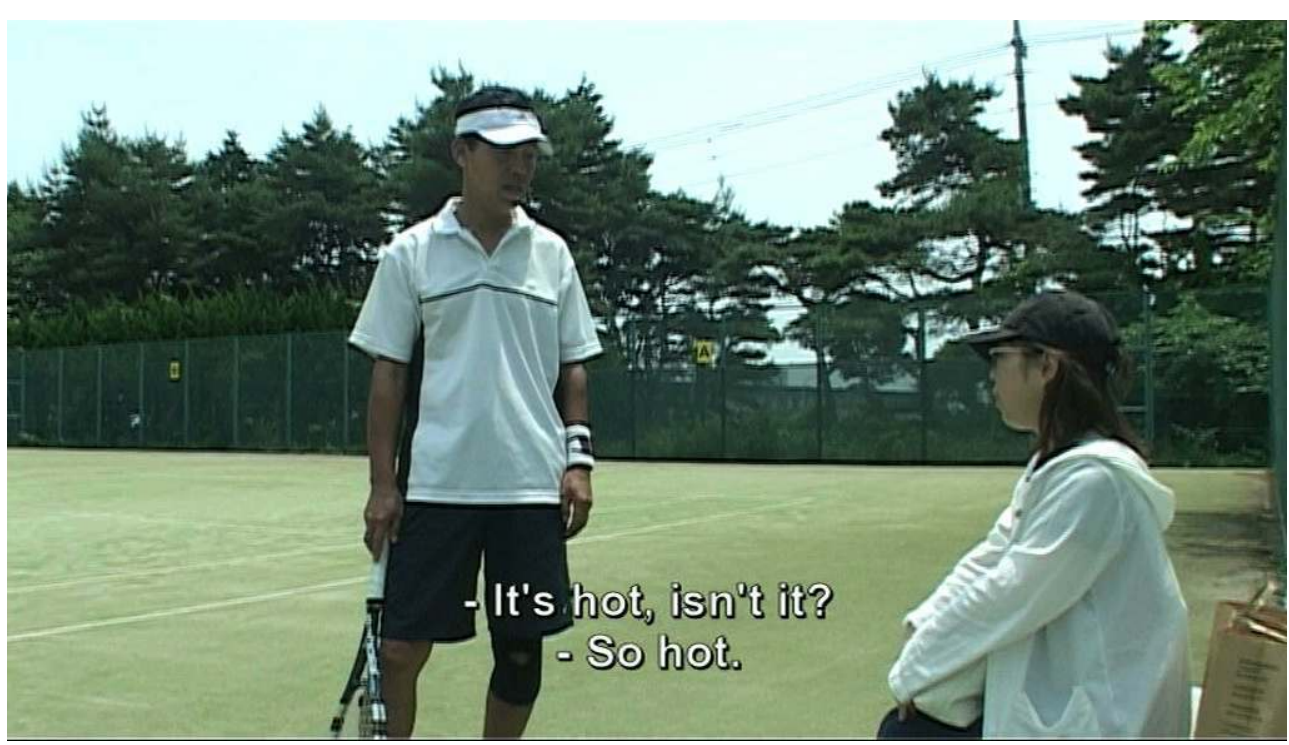

Screenshot of the film "Ippo Ippo" by Shotaro Wake 2010

Their first encounter at the tennis court suggests that both Marsha-san and Shimo-san do not know how to treat each other in the unfamiliar situation. Yet, they 'work hard' without saying much to reconcile their relationship in order to reduce the feelings of awkwardness. For instance, Shimo-san lets her (and me) sit on the bench next to where he plays, and brings her a cap to wear. Also, after the game Shimo-san offers her a cold drink, and says, "It's hot, isn't it?" and Marsha-san replies quickly "So hot". Her utterance of "Hot" sounds more like an expression of concern and care, which is different from when she was standing still and alone. Again, feeling very hot under the burning sun is a shared experience they can easily agree on, and therefore a safe topic in this public environment.

In the next shot, they are resting in the shade, being quiet. Here Marsha is standing while her husband sits on the bench. It shows who needs care in this situation, and the attention is given to her husband who is physically 'tired' from playing the game. Basso 
$(1970,216)$ reminds us to pay attention to who 'breaks' the silence, as well as when and how, because it reveals "the nature of [a person's] relationships to other people". In the Apache Indian context parents and children refrain from talking for a long time after having lived separately because of the children attending school in the city. Most often it is the children who break the silence. In this way the parents can observe if the children are still the same, and, let's say for instance, do not act disrespectfully toward the parents. Thus, what began as a feeling of 'hard to talk' is shaped into a feeling of 'easy to talk' with their children. This feeling of "easy to talk" is related to familiarity and predictability in the behaviours of others (Basso 1970, 221-222). In the scene, Shimo-san is the one who breaks the silence by saying, "It's really hot today" and Marsha-san nods. For Shimo-san, being with Marsha-san in silence does not seem to cultivate an 'easy to talk' feeling, familiarity or predictability. The utterance is a search for a topic of conversation to try to reduce the awkwardness between the two. However, interestingly, Marsha's response, "Are you going to play again?" seems an uncomfortable one for Shimo-san; for instance, Shimo-san lowers his voice and gives a blunt answer, "Unless you don't want me to." He almost takes it as an offence, as if she has already had enough of watching him play tennis after viewing only one match, rather than interpreting that she is concerned about her husband's physical condition in the extremely hot weather. Shimo-san goes on and plays more games despite Marsha's advice ("You'll wear yourself out"). After the game he hurries back to her and quickly starts packing his tennis bag to leave the field. He is not in a mood to share news about his game with her, and that seems to make Marsha-san frustrated by his behaviour. His frustration seems to be in line with a guilty feeling associated with 'leaving his wife hanging around' while he was playing tennis for himself. Feeling guilt for not taking good care of his visiting wife means playing tennis is not as much fun or as refreshing as it usually is for Shimo-san. Marsha-san reacts on the comment of Shimo-san, "What do you mean 'left to hang around'?", and she goes on saying that she would not have visited him at all unless Wake (the researcher) had asked her, and she would not return again. At this moment, despite the awareness that they are being filmed, they could not keep it 'cool' and started verbalising their frustration. Therefore, Shimo-san turns away and continues packing the bag rather than answering to Marsha-san. This is his way of avoiding further verbal conflict which they may think is embarrassing to show in public, especially on camera. In this sense, much of their frustration remains without being verbalised but it still affects the mood of both.

[Video:Left to hang around]

Click here to watch video:https://vimeo.com/104282027

Excerpt of the film "Ippo Ippo" by Shotaro Wake 2010

\section{Corporeal Resonance or Dissonance in Silence}

31 The tension between Shimo-san and Marsha-san continues until they go home. On the way back home, by the stairs, Marsha-san asks him to wait for her, and he offers her a hand. He says, "Hot", as soon as they hold hands and Marsha-san echoes the same word. They seem very shy about holding hands in front of the camera signifying closeness and intimacy despite feeling uneasy about each other in the moment. They then go up the stairs without talking. The way they walk together seems to express their feeling of uneasiness and awkwardness towards each other. For instance, they try to synchronise 
each other's footsteps physically yet do not quite make it and they let go of their hands as soon as they make it to the top.

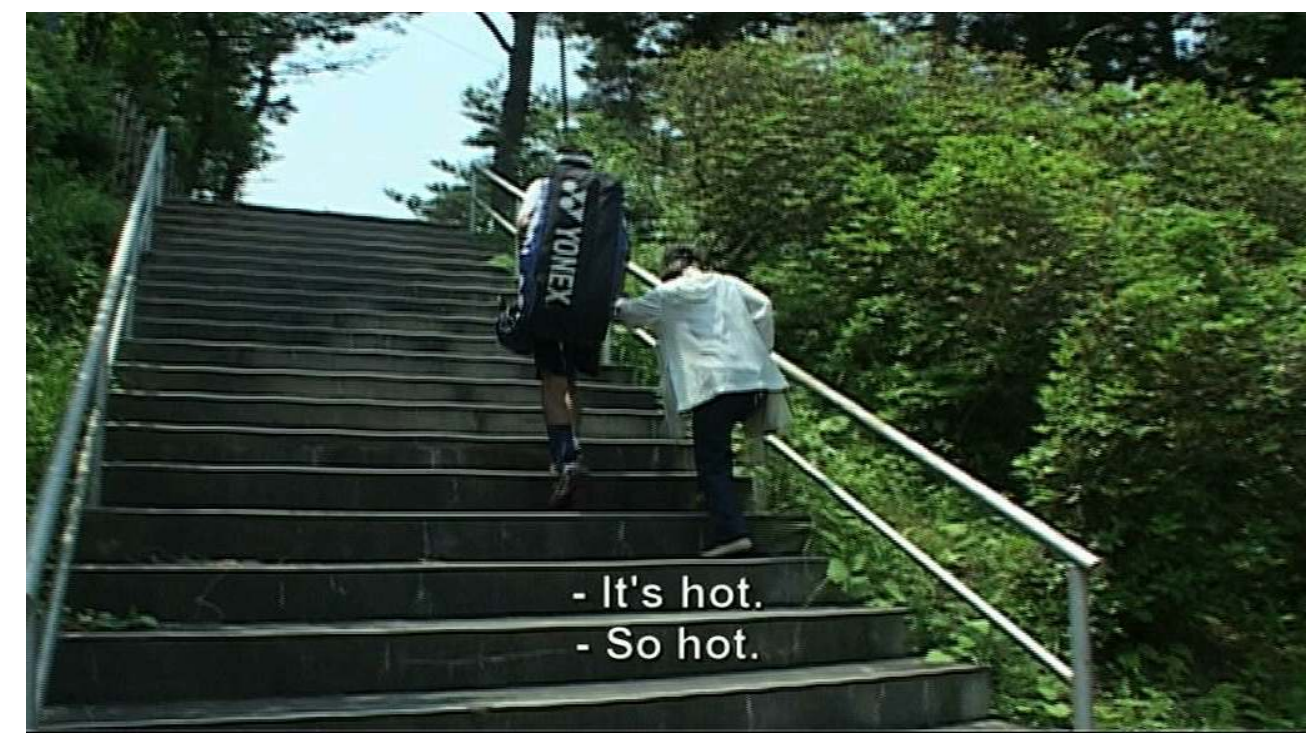

Click here to watch video: http://vimeo.com/104081348

Excerpt of the film "Ippo Ippo" by Shotaro Wake 2010

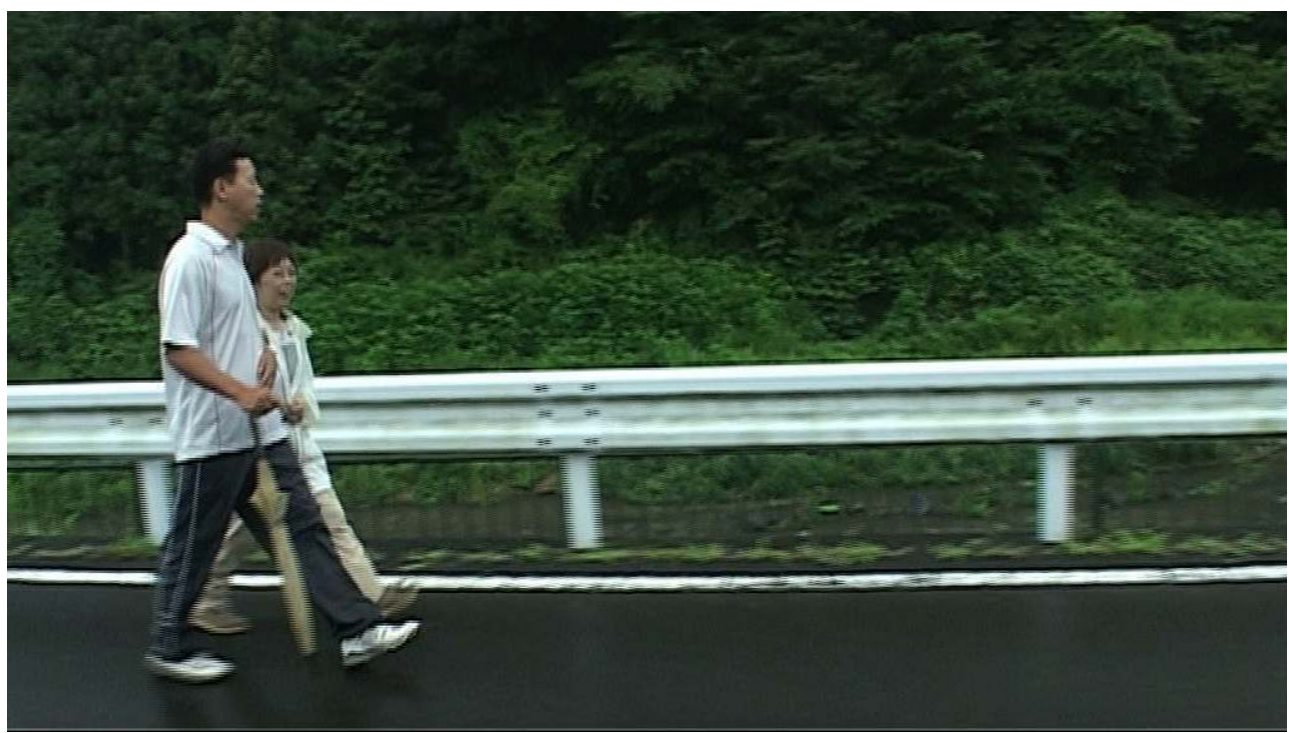

Click here to watch video: https://vimeo.com/104280956

Excerpt of the film "Ippo Ippo" by Shotaro Wake 2010

In these sequences, their walking paces and the rhythm of their motions are beautifully synchronised. She seems comfortable going along with her husband's walking speed and does not worry about the possibility of stumbling on a stone or anything else. Her body 
shows that she trusts her husband in this situation. The resonance emerges not only from their physical movements but also through their positive moods and the contents of their speech. On this walk, they also have to walk up some stairs and here too, as in the scene from the tennis court, their footsteps do not match (her husband is one step ahead); however, the difference is that they quickly re-match their footsteps after reaching the top, so that they again can regain a synchronised walk. This can be contrasted with the stairs at the tennis court where they quickly release each other's hands at the top. The difference in walking rhythm points to the fact that the couple could not recover their sense of familiarity and closeness on the day Marsha-san visited the tennis court, and it highlights that the boundary between illness and health usually remains hidden in their everyday life. Yet, the following episode suggests that her visiting experience certainly provided Marsha with a new understanding about how to treat the boundary between the two.

\section{New Understanding of the Boundary between the Couple}

Four years later I had a chance to catch up with Marsha-san at the cancer support group during my most recent fieldwork. She told me that she never went back to visit her husband at the tennis court. Yet, interestingly there seemed to be a positive change in her behaviour toward her husband's tennis playing as a result of seeing "another world", his world (Ippo Ippo 2010, 00:07:00 - 00:07:13). For instance, she now sometimes prepares 'rice balls' (onigiri) for him when he goes out for tennis which is something she never did before. It is a handmade lunch, tezukuri-bento, and a symbol of intimacy and support; although Marsha-san is not physically present, her handmade gift is carried into and appreciated in Shimo-san's "world". Marsha-san seems to understand now that her "world" is the cancer support group where she can feel free from her role as a housewife and enjoy quality time with other cancer friends and supporters. She said comically that if her husband were present at the support group meeting today, "I would act differently" and that would have spoiled their fun time. Other women also laugh to show that they could not agree with her more. This is most probably what she understood happened to Shimo-san when she visited him in his private sphere, creating awkwardness. Shimosan's tennis belongs to the world of the healthy and Marsha-san's cancer group belongs to the world of illness. A degree of acceptance of their differentiated positions due to her chronic conditions and his caregiver duty has been nourished in Marsha-san.

I also discovered that their decision to keep their interests and social relationships separate is not merely due to self-interest (to experience more fun and feel freer). There is also another important dimension that I initially did not understand. This became clear to me in my most recent research only after I started to socialise and engage with families affected by cancer, i.e. those who have experience in a role similar to Shimo-san. In the following video family caregivers (ongoing and past) speak highly about Shimo-san's attitude as a caregiver, especially his decision of not coming with Marsha-san to Mt. Fuji. They see it as a non-selfish choice and do not interpret it as a lie. Instead they see it as a clever choice and a generous consideration towards Marsha-san.

[Video: Discussing the support of Shimo-san] 


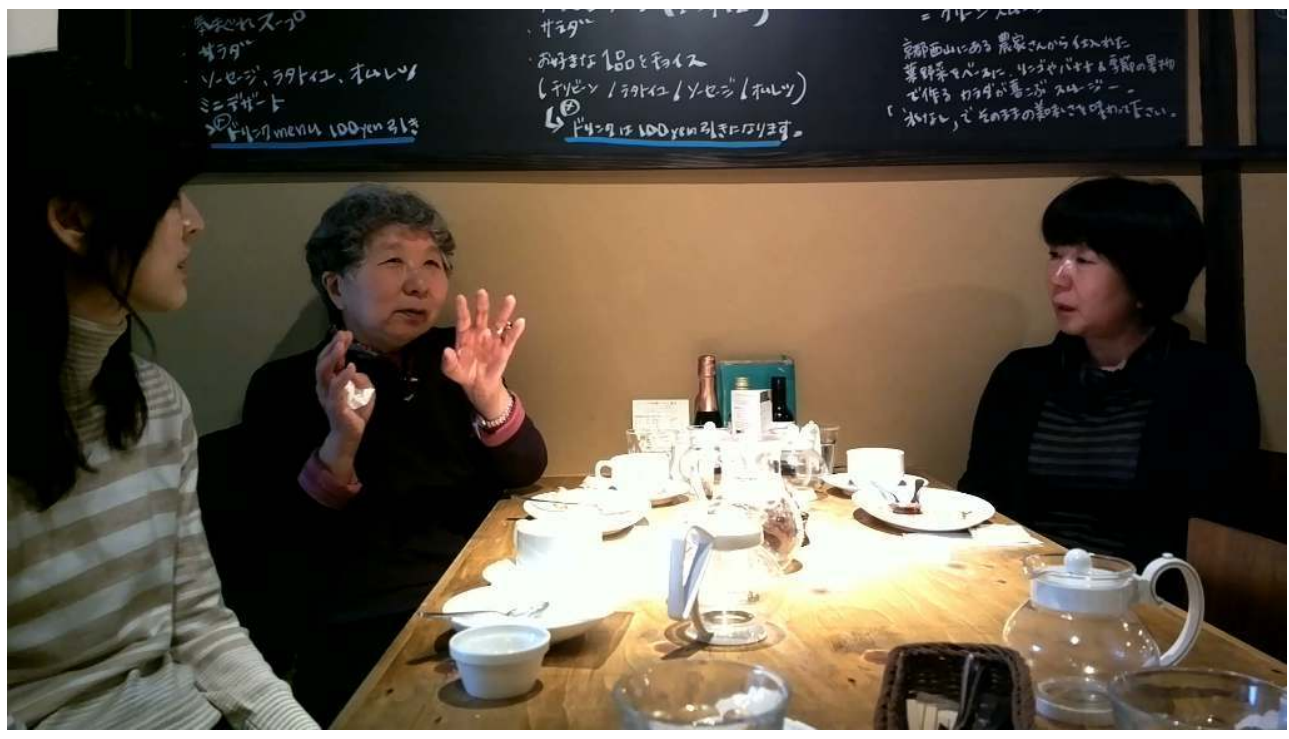

Click here to watch video: https://vimeo.com/104286471

Excerpt of the film "Ippo Ippo" by Shotaro Wake 2010

40 If the norm of good caregiver is related to a sense of participation as suggested by Long (1982; 2004), the way the caregivers discussed during the climb how the absence of the husband was a benefit and a means good support for Marsha-san was contradictory. In this way other supporters would feel more obliged to help Marsha-san and to consider her security; otherwise, they would feel hesitant about offering her a hand in front of her husband, and Marsha-san would also feel less able to openly seek help from the supporters who are mostly men. They could also empathise with how difficult it must have been for him to wait for her to come back home safely while bearing his difficult feelings. In this sense, I assume that when Marsha-san asked her husband while they were walking along in a friendly mood to join the climb the following year, his response of "Okay, I will" should perhaps be treated simply as a promise which he does not really intend to keep. This would be a cold, tsumetai, response. Rather, according to the caregivers interpretation, the meaning of his response comes out more like, "I would like to go with you although I think I had better not come with you." There is a resemblance here with Kagawa-Singer's case. Shimo-san is pretending as if he goes, iku-furi, together with Marsha, as expression of empathetic consideration of Marsha's condition. In fact, on the video, he looks down slightly to the ground before he replies to Marsha, as if thinking hard how to respond to her. 
Her husband pretends that he goes to Mt.Fuji with her

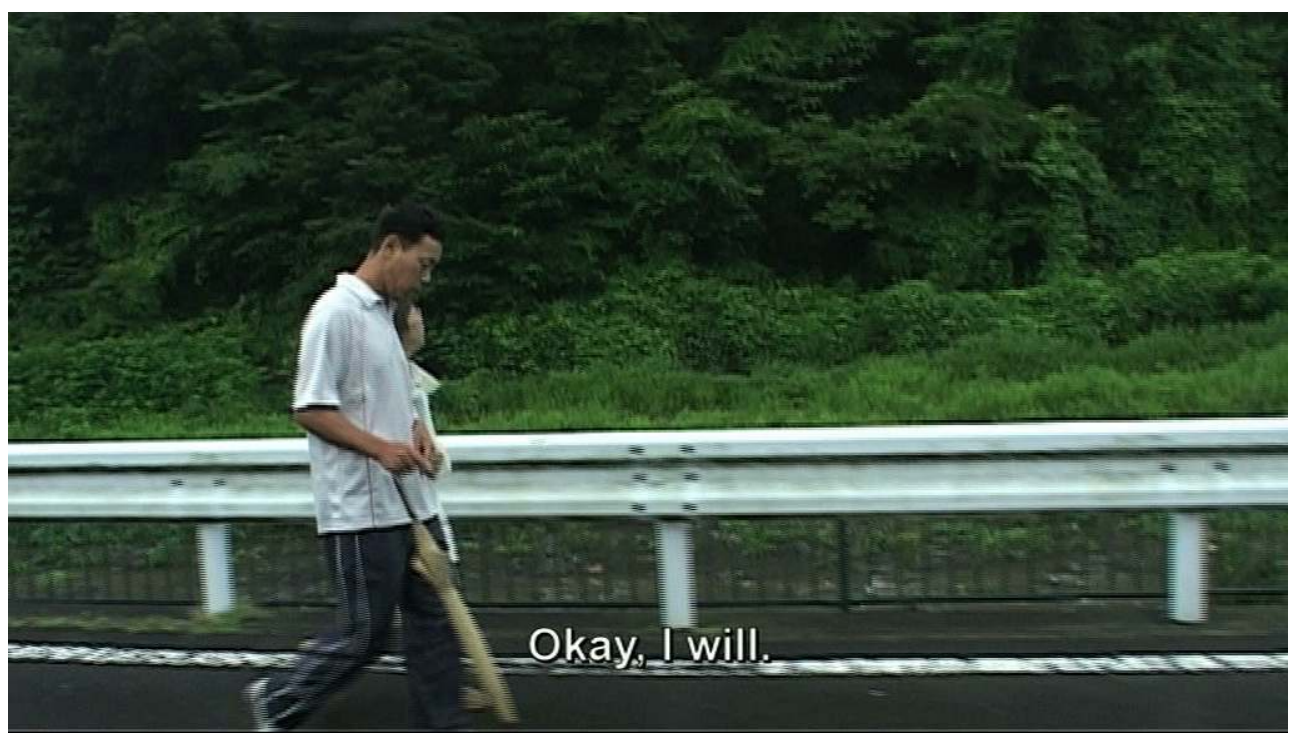

Screenshot of the film "Ippo Ippo" by Shotaro Wake 2010

41 Therefore, his response is more like an expression of his warm, attatakai, feelings toward Marsha-san. If I follow this logic further I start to think that perhaps Marsha-san's invitation is also a form of pretending, as if she invites him, sasou-furi, but it does not really matter if he really joins. Rather, she wanted to see how he would respond to her invitation. More simply, through talking about the trip to Mt. Fuji, they seem to actually check out their feelings towards each other. Based on this I would now say that when they walk arm and arm harmoniously their expression of feelings through the conversation is also in resonance. Although I have not filmed them further it could be an interesting question to pursue; for instance, how long does their resonance go on? In which moment does the resonance start to dissolve or transform into other forms, and how does this appear on the level of language, body, and context?

In such a moment of intimacy their physical, emotional, and verbalised actions all point in a certain direction, and their synchronised motions makes it difficult to observe the boundary of health and illness between the two. Shimo-san's response is one example of producing the possibility of something joyful for the future, and that is highly precious and welcome to people who suffer from illness and disability, as frightening and worrying possibilities are more common for them. Although such possibilities carry the risk of unexpectedly becoming a source of conflict because of the potential need to renegotiate boundaries (as was seen with the tennis - Marsha-san and Shimo-san both must have had a positive expectation of her visiting the tennis court before she arrived), I still believe they have enough experience and skills to cultivate 'good' teamwork to manage that risk creatively, as when they walk arm in arm, step by step, Ippo Ippo, during this rather tough journey. Ultimately, I believe that their long marriage is still atsui, hot, although I am certain that Marsha-san and Shimo-san would not publically agree on this. 


\section{Conclusion}

This article aims to provide a platform where the readers can become companions in the fieldwork for investigating fluid silence through visual microanalysis based on the scenes from the film Ippo Ippo (2010). I believe that the use of hyperlinks to various videos uploaded online can nourish a more convenient participatory experience for the readers who can read the text together with the visual material, hand in hand.

In this article I have discussed how expressions of silence, including short phrases like "Hot" are closely related to the couple's emotionally sensitive topic of Marsha's cancer diagnosis which they have never talked about, but kept wrapped. The encounter at the tennis court underlines the boundary that exists between the couple, not only as wife and husband, but also as sufferer and caregiver. The analysis follows the process of how they negotiate the boundary in worlds where they find each other strange and distant, and how they try to avoid an open verbal conflict while at the same time also trying to rebuild a sense of familiarity and predictability. Although the encounter comes out as a rather tough experience during the visit, four years later it certainly seems like the encounter has brought a new and positive change in the behaviour of Marsha-san, who seems to have started to appreciate and respect the boundary of her husband. As has been shown, the meaning of the utterance "Hot" differs from moment to moment, very much depending on the silence used, and it seems reasonable to argue that silence as a mode of being is constantly shifting in relation to utterance, body, relationship and circumstances.

5 This short article is a work in progress based on a chapter from my PhD thesis scheduled for publication at the beginning of 2016. I am currently working on elaborating the notion of fluid silence through visual media, and one of the approaches I use is to see how silences in different spaces have different meanings in local contexts, and how the dynamic phenomena between silence and illness is played out.

\section{BIBLIOGRAPHY}

\section{Books and articles}

Basso, Keith H. 1970. ““'To Give up on Words”: Silence in Western Apache Culture.” Southwestern Journal of Anthropology. 26(3): 213-230.

Becker, Gay. 1997. Disrupted Lives: How People Create Meaning in a Chaotic World. Berkeley, Calif.: University of California Press.

Collins, Peter and Sandra Bell. 1998. "Religious Silence: British Quakerism and British Buddhism Compared". Quaker Studies 3(1): 1-26 
Crapanzano, Vincent. 2003. "Reflection on Hope as a Category of Social and Psychological Analysis." Cultural Anthropology. 18(1): 3-32

Crapanzano, Vincent. 2004. Imaginative Horizons: An Essay in Literary-Philosophical Anthropology. Chicago, Ill.: London : University of Chicago Press 2003.

Ewing, Katherine P. 1990. "The Illusion of Wholeness: Culture, Self and the Experience of Inconsistency." Ethos 18(3): 251-278.

Hendry. 1993. Wrapping Culture - Politeness, Presentation, and Power in Japan and Other Societies. New York: Oxford University Press.

Huby, Guro. 1997. "Interpreting Silence, Documenting Experience: An Anthropological Approach to the Study Of Health Service Users' Experience with HIV/AIDS Care in Lothian, Scotland." Soc. Sci. Med. 44 (8): 1149-1160.

Hollan, D. 2008. "Being There: On the Imaginative Aspects of Understanding Others andBeing Understood." Ethos. 36(4): 475-489.

Kagawa-Singer, M. 1993. “Redefining Health: Living with Cancer.” Soc. Sci. Med. 37(3): 295-304.

Kakai, H. 2002. "A Double Standard in Bioethical Reasoning for Disclosure of Advanced Cancer Diagnoses in Japan." Health Communication 14(3): 361-376.

Merleau-Ponty, Maurice. 1968. The Visible and the Invisible: Followed by Working Note, ed. Claude Lefort. Translated by Alphonso Lingis. Evanston, Ill. : Northwestern University Press.

Jackson, Michael. 2004. "The Prose of Suffering and the Practice of Silence." A Journal of Christian Spirituality 4(1): 44-59.

Lebra, Takie S. 1976. Japanese Pattern of Behavior. Honolulu: University of Hawaii Press.

Lebra, Takie S. 1987. "The Cultural Significance of Silence in Japanese Communication.” Multilingua. 6(4): 343-357.

Lebra. Takie S. 2004. The Japanese Self in Cultural Logic. Honolulu: University of Hawaii Press.

Long, S. O., \& Long, B. D. 1982. “Curable Cancers and Fatal Ulcers: Attitudes toward Cancer in Japan. Soc. Sci. Med. 16: 2101-2108.

Long, S. O. 2004. "Negotiating the "Good Death": Japanese Ambivalence about New Ways to Die." Ethnology. 40(4): 271-289.

Mead, Margaret. 1995. "Visual Anthropology in a Discipline of Words.” In Principles of Visual Anthropology, ed Paul Hockings, Paul. New York: Mouton de Gruyter.

Montagu, Ashley, and Floyd Matson. 1979. The Human Connection. McGraw-Hill Book Company.

Ohi, Gen. 2011. Ningen-no-Oujyo. Mitori-no-Ishaga-Kangaeru. Tokyo : Shincho-shinsho.

Ohnuki-Tierny, Emiko.1984. Illness and Culture in Contemporary Japan - An Anthropological View. New York: Cambridge University Press.

Polanyi, Michael (1969). Knowing and Being, ed Marjorie Grene. London: Routledge \& Kegan Paul.

Radley, Alan. 1993. "Role of metaphor in adjustment to chronic illness." In Worlds of Illness Biographical And Cultural Perspectives On Health And Disease, ed. Alan Radley, 109-123. London: Routledge.

Radley, Alan. 2009. Works of Illness : Narrative, Picturing, and the Social Response to Serious Disease. InkerMen Press. 
Sacks et al. 1974. "A Simplest Systematics for the Organization of Turn-Taking for Conversation" Language. 50 (4.1) 693-735.

Scarry, Elaine. 1985. The Body in Pain : The Making and Unmaking of the World. Oxford: Oxford University Press.

Throop, C. Jason. 2008."On the Problem of Empathy: The Case of Yap, Federated States of Micronesia." Ethos 36(4): 402-426.

\section{Film}

Wake, Shotaro. 2010. Ippo Ippo. Visual Cultural Studies: University of Tromsø. http://youtu.be/ G4NdoSGsbok

\section{ABSTRACTS}

In this textual and visual online article I will present a visual microanalysis based on the ethnographic film I made in 2010, Ippo Ippo. The film focuses on how emotionally sensitive topics associated with cancer are dealt with among people living with cancer and those close to them. As several studies conclude, illness comes with suffering including pain that is not easy to talk about or listen to. This is especially true in a Japanese context where people generally prefer indirect communication, including silence, to avoid eliciting emotional communication. When we are faced with a combination of illness and Japanese communication style, we need to pay special attention to not only what people say but also what remains unsaid and the silence between words. Furthermore, how can an anthropologist get close to someone's personal experiences, especially in the realm of silence? That is, get close to the world of what people do not say or cannot say? I will draw attention to the fluid silence, seeing it as a mode of communication, as well as looking into the realm of silence. The article invites the readers to make their own microanalysis: while reading the text, the reader may view video clips from the film inscribed in the text.

Dans cet article visuel mis en ligne, je vais présenter une micro analyse fondée sur le film ethnographique que j'ai réalisé en 2010 , Ipo, Ipo. Le film aborde la manière dont des sujets émotionnellement sensibles en lien avec le cancer sont évoqués tant parmi les gens qui sont cancéreux et qu'avec ceux qui les accompagnent. Comme plusieurs études le démontrent, la maladie est accompagnée de la souffrance mais aussi de la douleur ce qui n'est ni facile à expliquer ni à entendre. Ce constat est d'autant plus vrai dans le contexte japonais où les gens préfèrent la communication indirecte, comme le silence, pour éviter toute communication explicitement émotionnelle.

Lorsque nous sommes confrontés à la maladie et à la communication au japon, nous devons être particulièrement attentifs à ce qui se dit mais aussi au non dit et au silence entre les mots. De plus, comment l'anthropologue peut il être proche de l'expérience personnelle de quelqu'un, tout en étant face au silence. Nous sommes proche du monde du non-dit ou de l'indicible. Je souligne l'importance de la fluidité du silence, le percevant tant comme un mode de communication que comme un espace. L'article invite les lecteurs à faire leur propre micro analyse : tout en lisant le texte, le lecteur peut regarder les vidéo clips du film décrit dans le texte.

En este artículo textual y visual presento un micro análisis visual basado en la película etnográfica que realicé en 2010, Ippo Ippo. Dicha película explora cómo las personas que padecen cancer y aquellas que viven cerca de éstas afrontan la enfermedad y aquellas cuestiones 
emocionalmente sensibles que plantea. Como sostienen varios artículos, no es fácil discutir sobre la el dolor y el sufrimiento que la enfermedad conlleva, como tampoco lo es escuchar testimonios hablando de ello. Esto es especialmente cierto en el contexto japonés, donde la gente prefiere generalmente la comunicación indirecta, incluyendo el silencio, evitando la comunicación emocional. La combinación de enfermedad y de sistema japonés de comunicación nos obliga a prestar especial atención no solamente a lo que la gente dice sino también a lo no dicho y al silencio entre palabras. Ahora bien, cómo puede el antropólogo o antropóloga adentrarse a las experiencias personales de alguien, y especialmente en el ámbito del silencio? Es decir, adentrarse al mundo de lo que no se dice o no se puede decir? Me centraré en el silencio fluido, interpretándolo como un modo de comunicación, y analizándolo dentro del ámbito del silencio.

\section{INDEX}

Keywords: visual ethnography, cancer, Japan, silence, communication

Palabras claves: etnografía visual, Japón, silencio, comunicación

Mots-clés: Ethnographie visuelle

\section{AUTHOR}

\section{SHOTARO WAKE}

$\mathrm{PhD}$ in Social Anthropology with visual media, the University of Manchester Shotaro Wake is currently doing a Ph.D in Social Anthropology with visual media at the University of Manchester. His research interest is based on his own cancer experiences, and his current project, Japanese Cancer Stories, will explore communication between cancer patients, their families, and health professionals in Japan. More specifically, Wake looks at how they use empathy to communicate emotionally sensitive topics and issues that are difficult to put into words alone.

shotaro.wake@postgrad.manchester.ac.uk 